2 Elhazmi MAF, Alfaleh FZ, Almofleh IA. Effect of Ramadan fasting on the values of haematological and biochemical parameters. Saudi Medical fournal 1987;8(2):171-6.

3 Sliman NA, Khatib FA. Effect of fasting Ramad on body weight and some blood constituents of healthy Muslims. Nutrition Report International 1988;38(6):1299-306.

4 Mohammad ZAN, Mohamad HH, Sayida N, Ishrat PS. Changes in blood urea and glucose and their association with energy-containing nutrients in men on hypocaloric diet during Ramadan. their association with energy-co

5 Begma IA, Khan IH. Variations in ionic concentration of blood serum during Ramadan fasting. Pakistan fournal of Science 1990;33:546-53.

6 Malak IS. Effect of fasting in Ramadan on plasma lipoproteins and apoproteins. Saudi Medical fournal 1986;7(6):561-5.

7 Mohamad HH, Mohammad ZAN. Body weight loss and changes in blood lipid levels in normal men on hypocaloric diets during Ramadan fasting. Am $\mathcal{F}$ Clin Nutr 1988;48:1197-210.

8 Kordy MT, Abdelgader AM. The effect of fasting in Ramadan on hemostatic variables. Annals of Saudi Medicine 1991;11:23-7.
9 Ali MR, Amir T. Effects of fasting on visual flicker fusion. Percept Mot Skills 1989;69:627-31. 10 Malhotra A, Scott PH, Scott J, Gee H, Wharton BA. Metabolic changes in Asian Muslim pregnan mothers observing the Ramadan fast in Britain. Br f Nutr 1989;61:663-712.

11 Prentice AM, Prentice A, Lamb WH, Lunn PG, Austin S. Metabolic consequences of fasting during Ramadan in pregnant and lactating women. Hum Nutr Clin Nutr 1983;37(4):283-94.

12 Cross JH, Eminson J, Wharton BA. Ramadan and birth weight at full term in Asian Moslem pregnant women in Birmingham. Arch Dis Child 1990;65:1053-6.

13 Prentice AM, Lamb WH, Prentice A, Coward WA. The effect of water abstention on milk rentice AM, Lamb WH, Prentice A, Coward WA.
synthesis in lactating women. Clin Sci 1984;66:291-8.

14 Aslam M, Healy MA. Drug regimens and fasting Moslem patients. $B M \mathcal{J}$ 1985;i:1746.

15 Laayam MA. Ramadan fasting and non-insulin dependent diabetes: effect on clinical control. East Afr Med f 1990;67:732-6.

16 Davidson JC. Muslim, Ramadan, and diabetes mellitus. BMF 1979;ii:1511-2.

17 Rashed AH, Siddique SA, Abu Romeh SH. Clinical problems during the fast of Ramadan. Lancet $1989 ; \mathrm{i}: 1396$.

\title{
Noise induced hearing loss
}

People who suffer from noise induced hearing loss may be greatly handicapped, unable to participate fully in normal social affairs, and depressed and lonely. As noisy environments increase ever more people are at risk of such loss. Recently the new National Institute of Deafness and Other Communication Disorders in the United States sponsored a consensus conference on noise and hearing loss. Its final statement, drafted by the usual multidisciplinary panel after expert presentations and an open debate, shows how little we know about the causes and consequences of noise induced hearing loss.

In the United States a little over 1 in 10 of the population suffer hearing loss, over one third of which is partially or wholly attributable to noise. Moreover, about 20 million Americans ( 1 in 13 of the population) are regularly exposed to hazardous sound level. Occupational causes are the most ubiquitous, but the additional effect of social and recreational exposure is important. Noise is thus a major public health problem, producing hearing loss at any age. Usually long exposure to excessive sound levels produces a gradual deterioration in hearing. The hearing loss is of variable severity and may be accompanied by tinnitus.

The consensus group agreed that a sound environment of below $75 \mathrm{~dB}$ was not harmful. Above that the amount of damage, the speed at which damage occurs, and the proportion of the population affected vary according to the sound level, the length of exposure, and individual susceptibility. For most industrial sound it takes daily exposure for several years to produce measurable damage. Above a certain level, however $-140 \mathrm{~dB}$ or so - a single sound may produce permanent damage. In spite of intensive study the biology of noise induced hearing loss is ill understood. Clearly there is a critical sound level above which mechanical damage occurs in the cochlea and below which other factors, including "biochemical and metabolic exhaustion," are critical. Temporary damage imperceptibly gives way to permanent damage as hair cells die. There is also some degeneration of cochlear nerve fibres and changes in the central nervous system. ${ }^{2}$

Clinical assessment of noise induced hearing loss may be difficult. Characteristically an audiogram shows an audiometric notch, with the hearing loss greatest somewhere between 3 and $6 \mathrm{kHz}$. Further exposure and aging, however, lead to disappearance of the notch, and the audiogram may be indistinguishable from that produced by many other causes. Although noise induced hearing loss is usually bilateral, some asymmetry is not unusual. Great individual variation is found, in both humans and experimental animals. More men than women are affected, which is assumed to be due to their being exposed to more noise rather than to their being more susceptible. In diagnosing hearing loss much emphasis is placed on pure tone hearing loss, but in fact the inability to discriminate speech, particularly against a background of noise, produces the greatest impairment. The measurement of ability to communicate is inexact, and better scales are urgently needed.

Controversy remains about how to equate risk to hearing with different sound levels and exposure times. Is it simply the total sound energy to which the ear is exposed, as enshrined in the International Standard ISO 1999e? Or should the less aggressive American paradigm be used, which takes into account rest periods between exposure? No consensus was reached. Ironically, the conference veered towards the international standard, at a time when great doubt is being cast on the equal energy concept in Europe (RRA Coles, personal communication). None the less, all sound above a certain level can be harmful, whether occupational or recreational, and the two are additive.

Prevention of noise induced hearing loss begins with education. Recreational devices such as power tools should be labelled as hazardous, the use of personal hearing protectors should be encouraged at play as well as at work, and parents should educate their children about proper sound levels for listening to audio devices through personal headsets. ${ }^{3}$ Comfortable hearing protectors should be more widely available. In the workplace greater educational efforts are required, government regulations should be monitored and implemented, and hearing conservation programmes should be given a higher profile. Enforcement of regulations governing workers' compensation might provide an incentive for better practices.

The consensus statement recommended further research, ranging from epidemiological studies to noise control engineering, from work on hearing protectors to basic biological research, including the genetic basis for susceptibility. After a century of research it is still not clear how noise damages the ear, but it is equally clear that this most common cause of acquired hearing loss in adults is totally preventable and that much human misery would be prevented if existing knowledge was implemented.

Professor of Otolaryngology,

P W ALBERTI

University of Toronto, Faculty of Medicine,

Toronto, Ontario,

Canada M5G 2C4

1 National Institutes of Health. Consensus Development Conference Statement. Noise and hearing loss. Bethesda, Maryland: NIH, 1990

2 Saunders JC, Cohen YE, Szymko YM. The structural and functional consequences of acoustic injur in the cochlea and peripheral auditory system: a five year update. F Acoust Soc Am 1991;90:136-46. 3 Clark WW. Noise exposure from leisure activities: a review. F Acoust Soc Am 1991;90:175-81. 